\title{
Agro-, der Schweiz und der Dritten Welt
}

Agrochimie, Suisse et Tiers Monde

\section{Vittorio Delucchi}

\section{(2) OpenEdition}

\section{Journals}

Édition électronique

URL : http://journals.openedition.org/sjep/1394

DOI : $10.4000 /$ sjep.1394

ISSN : 1663-9677

\section{Éditeur}

Institut de hautes études internationales et du développement

\section{Édition imprimée}

Date de publication : 1 janvier 1992

Pagination : 213-233

ISSN : 1660-5926

\section{Référence électronique}

Vittorio Delucchi, « Agro-, der Schweiz und der Dritten Welt », Schweizerisches Jahrbuch für

Entwicklungspolitik [En ligne], 11 | 1992, mis en ligne le 19 mai 2013, consulté le 08 septembre 2020

URL : http://journals.openedition.org/sjep/1394 ; DOI : https://doi.org/10.4000/sjep.1394

Ce document a été généré automatiquement le 8 septembre 2020.

(c) The Graduate Institute 


\section{Agro-, der Schweiz und der Dritten Welt}

Agrochimie, Suisse et Tiers Monde

Vittorio Delucchi

NOTE DE L'ÉDITEUR

Volltext auf Französisch in Annuaire suisse de politique de développement: „Agrochimie, Suisse et Tiers Monde", http://aspd.revues.org/1567. 